\title{
Influence of a modification of the petcoke/coal ratio on the leachability of fly ash and slag produced from a large PCC power plant
}

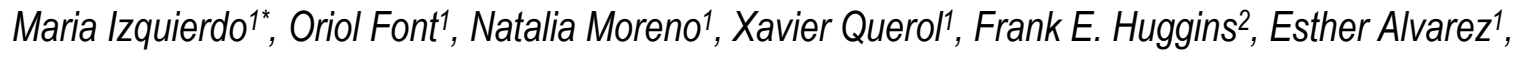
Sergi Diez', Pedro Otero ${ }^{3}$, Juan Carlos Ballesteros ${ }^{3}$, Antonio Gimenez ${ }^{3}$

1/nstitute of Earth Sciences "Jaume Almera" CSIC, Lluis Sole Sabaris s/n. 08028 Barcelona, Spain ${ }^{2}$ CME/CFFS University of Kentucky 105 Whalen Building 533 S. Limestone Street Lexington, KY 405060043, USA
\end{abstract}

${ }^{3}$ ENDESA GENERACIÓN S.A., Ribera del Loira, 60, planta 2, sector E, 28042, Madrid, Spain

CORRESPONDING AUTHOR: Telephone: +34934095410; Fax: +34934111112. E-mail:

mariaizq@ija.csic.es

\section{Supporting information}

Information available: 4 pages, 2 Tables, 2 Figures 
After calibration of the energy scale with respect to the zero-point of energy defined by the spectrum of the elemental standard, the normalized XAFS spectra were then divided into separate X-ray absorption near-edge structure (XANES) and extended X-ray absorption fine structure (EXAFS) regions. However, the spectral data obtained were only of sufficient quality for analysis of the XANES (X-ray absorption near-edge structure) region of the spectrum.
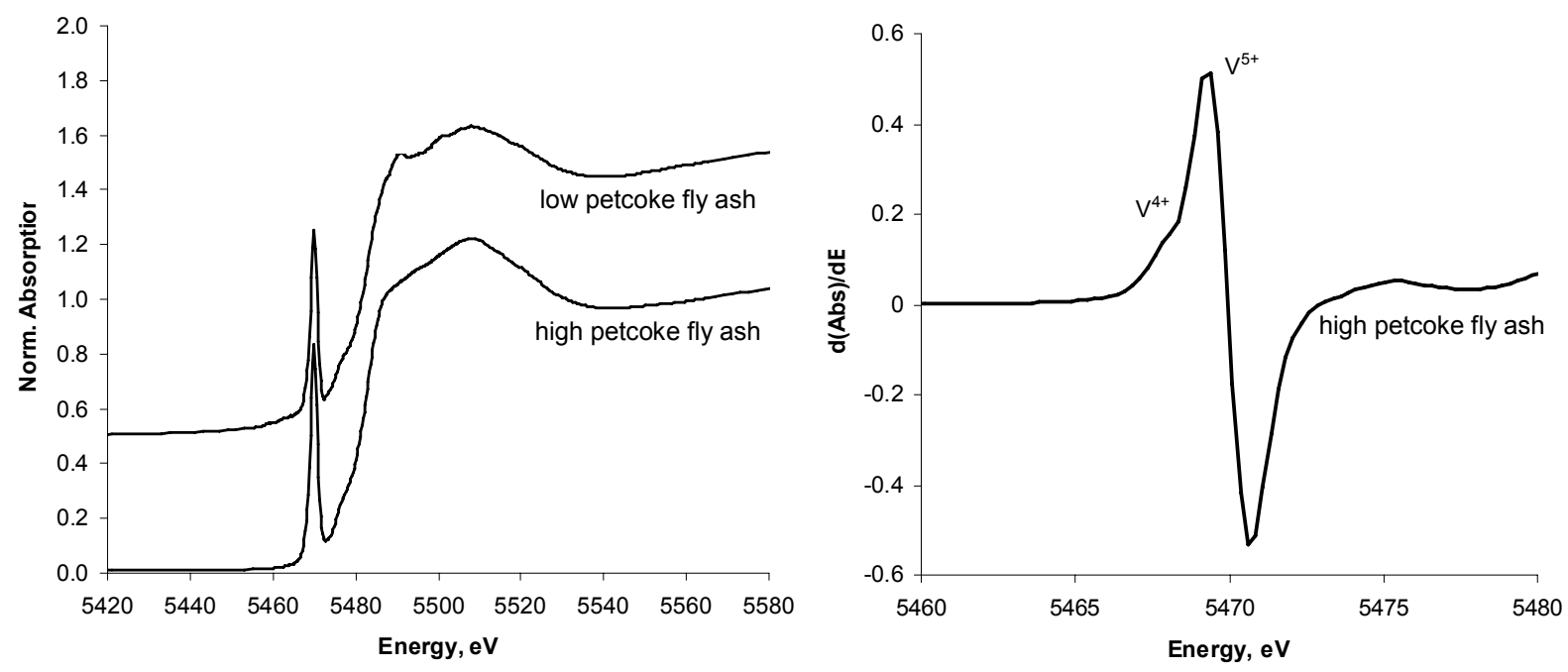

Figure S1. Comparison of V XANES spectra for the low and high-petcoke fly ash (left) and derivative spectrum of the pre-edge region for the high-petcoke fly ash (right).

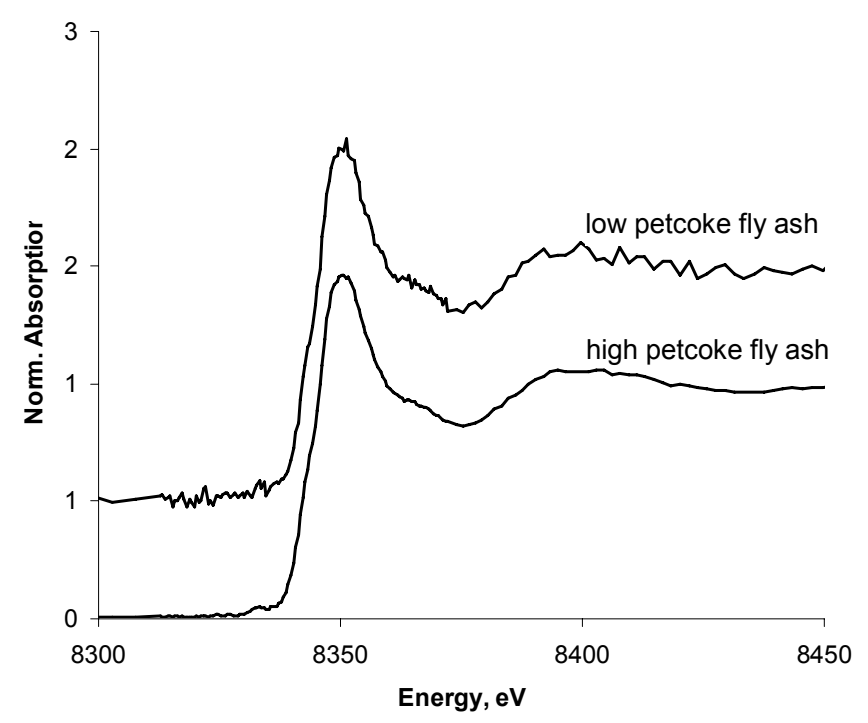

Figure S2. Comparison of Ni XANES spectra for the low and high-petcoke fly ash. 
Table S1. Bulk content, leachable content and water extractable fraction according to EN 12457-2 leaching test of a number of elements in the co-fired slag and fly ash selected in this study. The analytical error for each element is also shown.

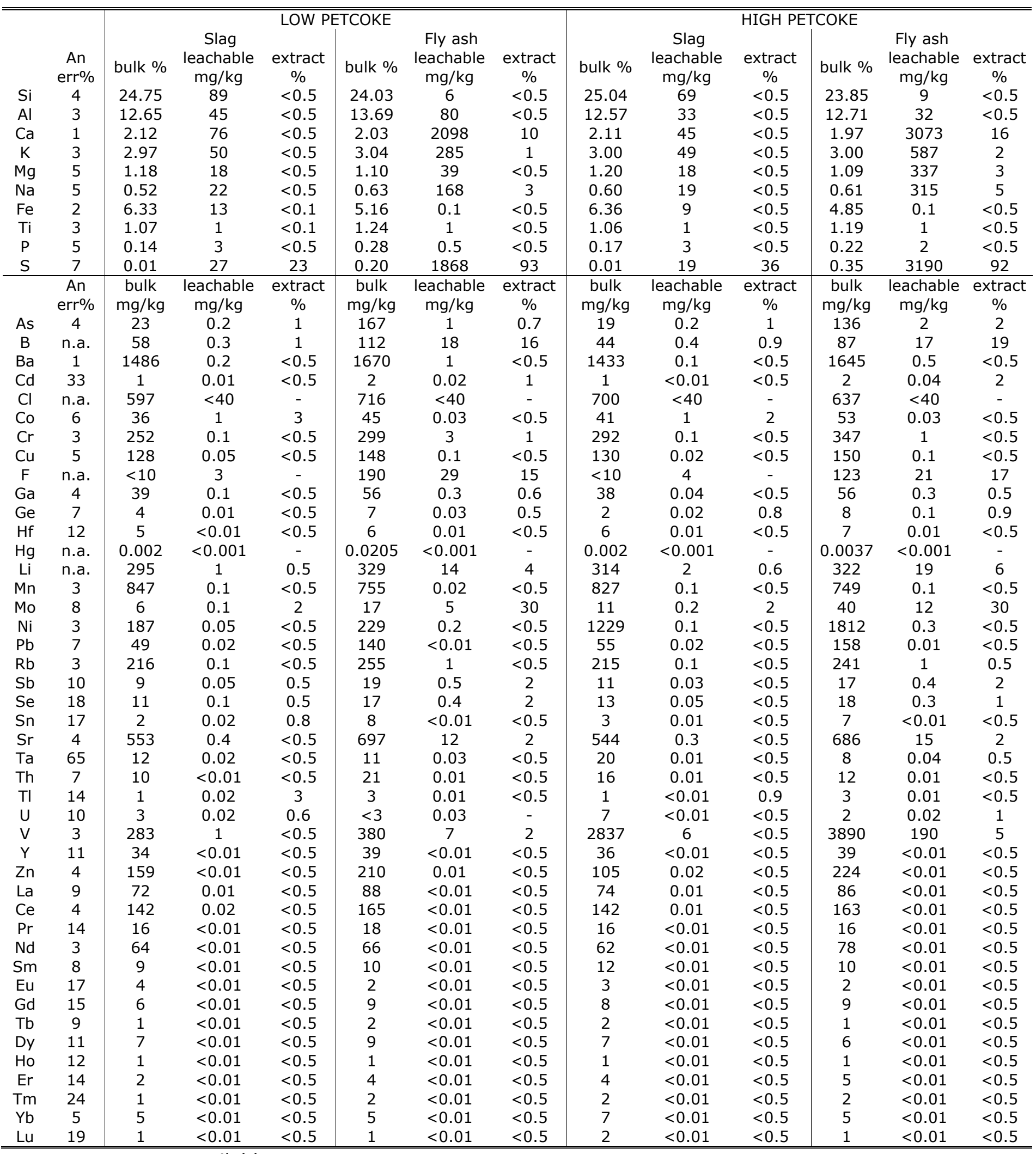

n.a.: not available 
Table S2. Criteria for the acceptance of waste at landfills based on RD 2003/33/EC (30) and comparison with leachable concentrations according to EN 12457-2 leaching test of the co-fired fly ash and slag selected in this study and p25-p75 range of PCC fly ash (18). Values in $\mathrm{mg} / \mathrm{kg}$.

\begin{tabular}{ccccccccc}
\hline \hline $\begin{array}{c}\text { p25-p75 } \\
\text { PCC EU range }\end{array}$ & & \multicolumn{3}{c}{$\begin{array}{c}\text { Category } \\
\text { Non }\end{array}$} & \multicolumn{2}{c}{ Low petcoke } & \multicolumn{2}{c}{ High petcoke } \\
Inert & $\begin{array}{c}\text { Nazardous } \\
\text { hazardous }\end{array}$ & sly ash & slag & fly ash \\
\hline $0.06-0.5$ & $\mathrm{As}$ & 0.5 & 2 & 25 & 0.2 & 1 & 0.2 & 2 \\
$2-8$ & $\mathrm{Ba}$ & 20 & 100 & 300 & 0.2 & 1 & 0.1 & 0.5 \\
$<0.01-0.01$ & $\mathrm{Cd}$ & 0.04 & 1 & 5 & 0.01 & 0.02 & $<0.01$ & 0.04 \\
$1-4$ & $\mathrm{Cr}$ & 0.5 & 10 & 70 & 0.1 & 3 & 0.1 & 1 \\
$0.04-0.08$ & $\mathrm{Cu}$ & 2 & 50 & 100 & 0.05 & 0.1 & 0.02 & 0.1 \\
$\mathrm{n} . \mathrm{a}$. & $\mathrm{Hg}$ & 0.01 & 0.2 & 2 & $<0.001$ & $<0.001$ & $<0.001$ & $<0.001$ \\
$3-5$ & $\mathrm{Mo}$ & 0.5 & 10 & 30 & 0.1 & 5 & 0.2 & 12 \\
$0.08-0.2$ & $\mathrm{Ni}$ & 0.4 & 10 & 40 & 0.05 & 0.2 & 0.1 & 0.3 \\
0.01 & $\mathrm{~Pb}$ & 0.5 & 10 & 50 & 0.02 & $<0.01$ & 0.02 & 0.01 \\
$0.01-0.2$ & $\mathrm{Sb}$ & 0.06 & 0.7 & 5 & 0.05 & 0.5 & 0.03 & 0.4 \\
$0.2-1$ & $\mathrm{Se}$ & 0.1 & 0.5 & 7 & 0.1 & 0.4 & 0.05 & 0.3 \\
$0.2-0.3$ & $\mathrm{Zn}_{\mathrm{n}}$ & 4 & 50 & 200 & $<0.01$ & 0.01 & 0.02 & $<0.01$ \\
$\mathrm{n} . \mathrm{a}$. & $\mathrm{Cl}$ & 800 & 15000 & 25000 & $<40$ & $<40$ & $<40$ & $<40$ \\
$\mathrm{n} . \mathrm{a}$. & $\mathrm{F}^{-}$ & 10 & 150 & 500 & 3 & 29 & 4 & 21 \\
$2391-5721$ & $\mathrm{SO}_{4}{ }^{2-}$ & 1000 & 20000 & 50000 & 351 & 6096 & 162 & 10420 \\
\hline $0.4-2$ & $\mathrm{~V}^{-}$ & - & - & - & & 7 & 6 & 190 \\
\hline \hline
\end{tabular}

n.a.: not available. 